\title{
A review of Fourier Transform Infrared (FTIR) spectroscopy used in food adulteration and authenticity investigations
}

Reema Valand, Sangeeta Tanna, Graham Lawson, Linda Bengtström

School of Pharmacy, Faculty of Health and Life Sciences. De Montfort University; Leicester LE1 9BH, UK

Corresponding author:

Linda Bengtström

School of Pharmacy, Faculty of Health and Life Sciences

De Montfort University; Leicester LE1 9BH, UK

linda.bengtstrom@dmu.ac.uk 


\section{A review of Fourier Transform Infrared (FTIR) spectroscopy used in food adulteration and authenticity investigations}

\section{Abstract}

2 The increasing demand for food and the globalisation of the supply chain, have resulted in a rise in food 3 fraud, and recent high profile cases, such as the Chinese milk scandal in 2008 and the EU horsemeat 4 scandal in 2013 have emphasised the vulnerability of the food supply system to adulteration and 5 authenticity frauds. Fourier Transform Infrared (FTIR) spectroscopy is routinely used in cases of 6 suspected food fraud as it offers a rapid, easy and reliable detection method for these investigations. In

7 this review we first present a brief summary of the concepts of food adulteration and authenticity as 8 well as a discussion of the current legislation regarding these crimes. Thereafter, we give an extensive 9 overview of FTIR as an analytical technique and the different foods where FTIR analysis has been employed for food fraud investigations as well as the subsequent multivariate data analysis have been applied successfully to investigate case of adulteration or authenticity. Finally, we give a critical discussion of the applications and limitations of FTIR, either as a standalone technique or incorporated in a test battery, in the fight against food fraud.

14 Key words: FTIR, food fraud, food adulteration, food authenticity, spectroscopy 


\section{Introduction}

With the increasing globalisation of the food supply chain, with several stakeholders in between 'farm to fork', and the intrinsic vulnerability of such a system, food quality and safety have become of increased concern for consumers, food producers and governments (US Food and Drug Administration, 2009; European Comission, 2018). Scandals such as the addition of melamine in baby formula in China in 2008 (Pei et al., 2011), the European horse-meat scandal in 2013 (Premanandh, 2013), and the issue of peanuts and almonds found in ground cumin and paprika in Europe and the US in 2015 (Agres, 2015), all illustrate the negative impact of food fraud, including both adulteration and authenticity.

Although there is no harmonised definition of food fraud in the EU, it is generally accepted by the member states that food fraud are committed 'intentionally for financial gain through consumer deception' (European Comission, 2018). The criminal activity of intentionally adulterating food has gradually become more prevalent due to the associated incomes (Galvin-King, Haughey and Elliott, 2018). Food adulteration can be defined as the process in which the quality of food is purposefully degraded either by the addition of low-grade quality material or by extraction of valuable ingredients (Spink and Moyer, 2011) Nowadays, the most common foods categories susceptible to any type of food fraud are in descending order; olive oil, fish, organic foods, milk, grains, honey and maple syrup, coffee and tea, spices, wine and certain fruit juices (Moore, Spink and Lipp, 2012; Hoffman, 2013a). The so-called premium food products, such as meat (Rohman et al., 2011; Nunes et al., 2016a), spices and herbs (Lohumi et al., 2017a; Wielogorska et al., 2018), honey (Amiry, Esmaiili and Alizadeh, 2017), olive oil (Rohman and Man, 2010; Georgouli, Martinez Del Rincon and Koidis, 2017a), and coffee (Reis et al., 2017) are particularly susceptible to adulteration, especially when they are produced and supplied through complex supply chains (Black et al., 2016). Expensive commodities are vulnerable to economically motivated adulteration (EMA) due to the large incomes generated from these products (Galvin-King, Haughey and Elliott, 2018).

Conversely, cheap foods, such as milk and grains, are also susceptible to adulteration, mainly due to the low margins of profit (Smith, Manning and McElwee, 2017). For instance, the increased consumption of milk, due to its high nutritional value, has made it prone to fraudulent activity 
(Handford, Campbell and Elliott, 2016). Additionally, $21^{\text {st }}$ century agriculture faces multiple challenges due to increasing global population, such as an increasing demand on food production for humans and livestock as well as increased demands on feedstock for the bioenergy market (FAO, 2009). The agricultural sector also faces demands due to the developments in the agriculture-dependent developing countries and the adaptation to more efficient and sustainable production methods and climate change (FAO, 2009). All of these factors are important when understanding the reasons for food fraud. Although it is not currently known how common food fraud is, it is estimated that the cost for the global food industry could be as high as US\$40 billion dollars annually (PwC, 2016).

Depending on the adulterant used, food fraud could have severe adverse health effects, such as the development of cramps, nausea, diarrhoea, vomiting, nerve damage, allergic reactions and paralysis (Sicherer, Burks and Sampson, 1998). For instance, in 2015 there were reports of the addition of peanuts and almonds to cumin and paprika powder in the USA and Europe (Agres, 2015). The unintentional ingestion of these two allergens could potentially lead to severe or even lethal allergic reactions (Sicherer, Burks and Sampson, 1998). Other common allergens found in contaminated food are fruits, soybeans, fish, milk, egg, tree nuts, wheat and shell fish (Añíbarro, Seoane and Múgica, 2007) all of which can cause severe health problems.

The scandals concerning fraudulent foods have increased the pressure on food laboratories to develop fast and reliable screening methods for the detection of food fraud. One of the most commonly used screening techniques for food fraud today currently is Fourier Transform IR (FTIR) based on mid infrared (MIR) vibrational spectroscopy, as it offers a rapid and reliable detection method and in this review we describe the use of FTIR as a tool to investigate food adulteration and food authenticity. The first part of this review offers an overview of food adulteration and authenticity from a historical and current global perspective. The second part introduces FTIR as a screening technique and discusses the theory behind this technique. Finally, the third part of this review offers a critical discussion of the use of FTIR and multivariate analytical tools, on their own or as part of a battery of techniques as a method to investigate different food matrices. 

adulteration and authenticity since Rodriguez-Saona and Allendorf published their review in 2011 (Rodriguez-Saona and Allendorf, 2012) and considering the recent advances in the analytical techniques as well as the recent high profile food scandals, it is therefore a timely addition to the discussion of food authenticity and adulteration.

Food adulteration and authenticity

Legislation and industry standards

In the United States (US), the two primary agencies for food safety, and thus for food fraud and authenticity, are the US Department of Agriculture (USDA) and the US Food and Drug Administration (Johnson, 2014). The primary legislation concerning food safety; governing food, drug and consumer protection, is the Federal Food, Drug and Cosmetic Act (FFDCA) from 1938 (United States Congress, 1938). In 2011, the Food Safety Modernization Act (FSMA) was signed into law, 
awarding the FDA further authorities such as a mandatory recall authority (United States Congress, 2011), deemed necessary due to reported incidents of foodborne illnesses during the early 2000's.

It is important to emphasise that not all levels of contamination are considered intentional adulteration. Most national and international legislations as well as industrial organisations today have a threshold for extraneous matter to allow distinction between accidental and intentional contamination. For instance, the threshold for gross adulteration for horsemeat in the UK is when food items contain $1 \%$ weight by weight (w/w) or above of extraneous material (Food Standards Agency, 2015). In the US, the FDA have established the Food Defect Action Levels in order to distinguish between 'natural or unavoidable' defects, where adulteration is one of many causes, for a range of commodities (US FDA, 2018). An example of an industry organ with its own thresholds is the European Spice Association (ESA), with a maximum of $2 \% \mathrm{w} / \mathrm{w}$ for extraneous material for herbs and $1 \% \mathrm{w} / \mathrm{w}$ for spices (ESA, 2015). However, with recent developments in increasing sensitivity of the methods employed, such as DNA tests and analytical chemical methods, to detect food fraud, very low concentrations of a contaminant could be detected (Galvin-King, Haughey and Elliott, 2018). These thresholds are therefore in place to differentiate between contamination and intentional adulteration, and are set based on the limit of detection for the particular analytical technique used to detect the adulteration (Downey, 2016).

Testing for food authenticity is important to ensure that food offered for sale or sold is of the nature, substance and quality expected by the purchaser (Defra et al., 2014). If manufactures fail to correctly and honestly state what ingredients are present within the food item, it becomes deception and is then classified as food crime (Defra et al., 2014). There are therefore harmonised regulations in the EU on food labelling, presentation and advertising aim to protect consumers and facilitate trade inside and outside Europe (European Commission, 2000). In 2006 the European Council Regulation introduced three different types of quality logos for ensuring authenticity of agricultural products and foodstuff (The Council of the European Union, 2006). Two of these logos - the Protected Designation of Origin (PDO) and the Protected Geographical Indication (PGI) - have a specific link to the region where the product comes from, while the third one - the Traditional Speciality Guaranteed (TSG) logo 
highlights a traditional production process (The Council of the European Union, 2006). In practicality, this directive regulates food or drinks that are produced must adhere to a precise set of specifications to be labelled with any of the three logos (The Council of the European Union, 2006). As an example, as wine is a premier agricultural product of the EU and exported worldwide, the EU has taken serious action to maintain the reputation of the wine producing companies and other food manufacturers. Since 2011, the EU also has specific regulations for wine authenticity since 2011. Wine adhering to the specifications set by the framework is now categorised according to PDO and PGI (The European Commission, 2014b, 2014a).

\section{Food adulteration throughout history}

One subcategory of food fraud is Economically Motivated Adulteration (EMA), which can be defined as the intentional contamination of food for increased profit (Spink and Moyer, 2011). Not only is EMA a fraudulent activity that might harm consumers trust in a specific food category or company (GMA and Kearney, 2010; Kendall et al., 2018), it might also directly or indirectly have adverse effects on consumers health by the addition of potentially harmful substances to the food (Spink and Moyer, 2011). However, EMA is by no means a contemporary phenomenon and is likely to be as old as the food processing and production systems themselves (Ellis et al., 2012). Historical examples of EMA are the addition of lead to soured wine in ancient Rome, or adding the drug cocculus indicus in order mask the smaller amounts of hops and malt used during brewing or mixing alum with flour in bread to make it whiter (Evershed and Temple, 2016).

The first researcher to apply scientific methods to detect food adulteration was Frederick Accum, who made the first serious attempt to expose both the extent and dangers of food adulteration in 1820 (Accum, 1820). However, more than half a century after Accum first published his book, food adulteration was still so rife that a journalist for the New York Times wrote that most people were not aware of "what abominable messes they are constantly putting down their throats under the most innocent disguises' (Evershed and Temple, 2016). 
Even though modern food adulteration is usually more sophisticated than these historical examples, it is no less prevalent, and only in the last decade, there have been several high profile cases linked to food adulteration and authenticity. In 2008, elevated levels of melamine was found in the products of 22 Chinese dairy companies (The Associated Press, 2008), and this contamination led to the death of six infants and the hospitalisation of over 52,000 small children (Pei et al., 2011). Melamine is an organic base which is used to make plastics, fertilisers and concrete, and can cause kidney stone formation that in certain risk groups can trigger acute renal failure (Skinner, Thomas and Osterloh, 2010). When melamine is added to food products, it mimics a higher protein content of a diluted food (Pei et al., 2011), and this unapproved enhancement of the milk is a case of the devastating consequences EMA can have (Lakshmi and Pradesh, 2012). The melamine scandal in China also illustrates the vulnerability of food safety regulation if official controls do not efficiently assure the implementation of existing legislation (Pei et al., 2011).

Another highly publicised food scandal is the so-called '2013 horsemeat scandal' in Europe in which food products marketed as beef were found to contain high levels, sometimes up to $100 \%$, of undeclared or improperly declared horse meat (BBC News, 2013). This case, where cheaper horsemeat was mislabelled as expensive beef, highlighted several vulnerabilities within the European food supply chain (Department of Agriculture Food and and Marine, 2013; Elliott, 2013). For instance a complex network of traders and grocers, which may contain farmers, primary processor, local traders, secondary processor, exporter, importer, trader, processor/packager, retailer and finally consumer, cause a lack of transparency in this part of the supply chain (Department of Agriculture Food and and Marine, 2013; Elliott, 2013; Galvin-King, Haughey and Elliott, 2018). In the aftermath of the horsemeat scandal, it was concluded that the control of food safety also need to involve checks on food authenticity (Department of Agriculture Food and and Marine, 2013).

One of the more recent cases of EMA with potentially severe adverse health effects for the public is the adulteration of ground cumin and paprika sold in Europe and the US by the addition of peanuts and almonds (Agres, 2015). The unintentional ingestion of peanuts or almonds could potentially lead to severe or even lethal allergic reactions (Sicherer, Burks and Sampson, 1998) and detection of 
such adulterations is of high interest. This is also an example whereby adulteration associated with EMA is driven by crop failures (Bawden, 2015). Whenever there is a crop failure of a certain commodity, that commodity shows an increased susceptible to food fraud, similar to any food with a sudden increase in price or demand (Bawden, 2015; Black et al., 2016).

Yet another example of adulteration of a food product in high demand is the dilution of expensive extra virgin olive oil (EVOO) with cheaper vegetable and seed oils (Dalmia, 2015). This also results in a lower the nutritional value further adding to the fraudulent nature of the adulteration (Dalmia, 2015). The adulteration of olive oil using unhealthy substitutes is therefore considered a threat for public health $(\mathrm{Ok}, 2017)$. The increased global demand for olive oil coupled with the recent years of drought in the Mediterranean regions, has seen a steep rise in the prices of EVOO (Schrieberg, 2017), making adulteration particular profitable. Adulteration of EVOO has therefore recently been recognised as a common problem for regulatory agencies, oil suppliers and consumers (Dalmia, 2015). For instance, in 2012, two Spanish businessmen were sentenced to prison after they were found trading hundreds of thousands of litres of EVOO adulterated with sunflower oil (70-80\%) (Henley, 2012).

\section{Food authenticity as an emerging issue}

The authenticity of food can be understood as how honestly and accurately the food item has been marketed and trading of inauthentic foods is currently a large economic problem (Hansen, 2015). In order to protect consumers and implement food laws, it is important to verify the labelling of food in relation to composition, processing or origin (Primrose, Woolfe and Rollinson, 2010). The determination of authenticity is important so that consumers can make informed choices in relation to health concerns, religious beliefs or lifestyle choices (Primrose, Woolfe and Rollinson, 2010). Food products that are marketed claiming to contain natural ingredients or originating from a special location produced using local and traditional methods become difficult to verify unless thoroughly checked (Hansen, 2015). Trading of inauthentic foods is currently a large economic problem (Hansen, 2015).

Food authenticity is a growing concern due the consequences deceptive marketing can have on consumer health and trust. Moreover, the country or region of origin of certain commodities or 
products that meet the standards of organic farming, such as saffron (Anastasaki et al., 2010), olive oil (Gouvinhas et al., 2015), honey (Gok et al., 2015) as well as wine (Cozzolino et al., 2009a) and wine derived products (Ríos-Reina et al., 2017) will greatly impact the retail price. This increased price makes these products vulnerable to food fraud due to the economic gains associated with the substitution with a cheaper ingredient. For instance, the price of saffron is very much dependent on the country of origin (Anastasaki et al., 2010), and there have been reports showing that more than $50 \%$ of saffron labelled as the prestigious and Protected Designation of Origin (PDO) Spanish saffron could be grown and/or processed in other countries, such as Iran (Govan, 2011; Rubert et al., 2016).

Similarly, olive oils from certain PDO regions or countries, such as Sabina (Lazio), will also fetch a higher price due to their unique qualities in flavour and/or production technique (Bevilacqua et al., 2012a). The verification of authenticity of a food product is however a complex issue, where the entire food product is usually analysed in a non-targeted analysis (Bevilacqua et al., 2012a). In these cases, no foreign material has been added to the food product and only small chemical differences in several variables between the authentic and the fraudulent product are analysed, which requires multivariate statistical techniques, such as partial least squares (PLS), principal component regression (PCR), principal component analysis (PCA) or Soft Independent Modeling Class Analogy (SIMCA) to distinguish between foods with very similar chemical composition (Granato et al., 2018).

From the cases presented above it is clear that food fraud is neither a new phenomenon, nor something that is expected to decrease within the foreseeable future. Even if the food safety legislation has become more stringent in modern times, there is need for official controls using scientific methods to ensure that these regulations are implemented. It is clear that food fraud has been and will be posing a threat not only to the food industry in terms of loss of consumer trust and ultimately profits, but also, and more importantly, to consumers in the shape of potentially adverse health effects. These examples of food fraud also illustrate the need for a rapid, easy and reliable detection technique in order to analyse a larger subset of food for adulteration and authenticity, and thus discourage fraudulent activities. 


\section{FTIR vibrational spectroscopy as a detection technique}

\section{Introduction to infrared vibrational spectroscopy}

226

227

228

229

230

231

232

233

234

Mid-IR (MIR) spectroscopy as an analytical technique measures the absorbance of IR radiation of dipole bonds within functional groups of molecules (Chalmers and Griffiths, 2002a; Gauglitz and VoDihn, 2003). The absorbance of IR radiation excites the electrons in the bonds to a higher state of vibration (Gauglitz and Vo-Dihn, 2003), causing bending or stretching motions of the molecular bonds (Chalmers and Griffiths, 2002b). A molecule will absorb IR radiation only if the absorption of the particular wavelength causes a change in the at-rest and excited vibrational states (Amand and Tullin, 1999). Most chemical compounds, except for instance elemental diatomic gases such as $\mathrm{N}_{2}, \mathrm{H}_{2}$ and $\mathrm{O}_{2}$, have a dipole moment and can be analysed by their characteristic infrared absorption (Amand and Tullin, 1999).

For organic compounds, characteristic stretching vibrations usually occurs between 4000-1500 $\mathrm{cm}^{-1}$, in the so-called MIR region (Gauglitz and Vo-Dihn, 2003). However, below $1500 \mathrm{~cm}^{-}$ ${ }^{1}$, vibrations, generally bending, result in a characteristic fingerprint of the molecule or a large part of the molecule and can therefore give structural information useful for identification (Stuart, 2005). Moreover, the intensity of the absorbance is directly proportional to the concentration of a pure compounds or that particular feature when analysing mixtures (Gauglitz and Vo-Dihn, 2003), further making IR spectroscopy suitable for quantitative purposes. 
244 FTIR instruments utilise the interference between two IR beams to yield a signal, called an 245 interferogram, which is a function of the change in path length between the two beams (Stuart, 2005).

246 This is usually achieved using a Michelson interferometer, see Figure 1. The generated signal from a 247 Michelson interferometer can then be decomposed into the frequencies that form a signal, using Fourier 248 Transform algorithms (Stuart, 2005). The Michelson interferometer, first described in 1881 (Michelson, 249 1881, 1927), consists of a light source, such as a mercury arc, tungsten or a globar lamp, a semireflecting beamsplitter and two perpendicular mirrors, one stationary and one moving (Stuart, 2005; Albert, Albert and Quack, 2011a). In the first part of the interferometer a collimated IR beam is split with equal intensity by a beamsplitter (Gauglitz and Vo-Dihn, 2003). These divided beams are then reflected by both the stationary and moving mirrors back to the beamsplitter, where they recombine and interfere, see Figure 1 (Gauglitz and Vo-Dihn, 2003). This interference, either constructive or destructive in the recombined beam, are caused by the moving mirror producing a difference in path length (Stuart, 2005).

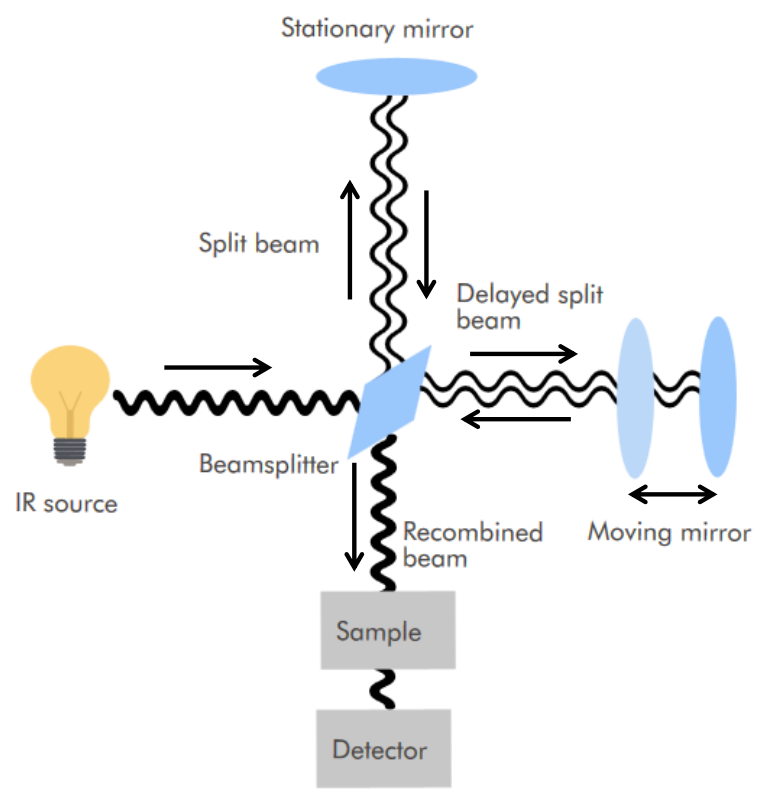

Figure 1. Schematics of a Michelson interferometer used in modern FTIR instruments. Adapted from Albert, Albert and Quack (2011) 
Although the Michelson interferometer was developed in the late 1800's, it was not until 259 the late 1970's the methodology revolutionised high resolution IR, when the bottleneck of computational power to perform an Fourier transformation on high resolution IR data was overcome (Albert, Albert and Quack, 2011b). The Fourier transformation convert the obtained interferograms, presenting intensity versus time, to an IR spectrum, showing intensity versus frequency (Gauglitz and Vo-Dihn, 2003). Prior to the computer revolution in the late 1970's, the resolution of most FTIR instruments were comparable to the dispersive instruments (Albert, Albert and Quack, 2011b). Currently, the resolution of an FTIR instrument is limited by the maximum path difference between the two beams reflected by the mirrors (Stuart, 2005), see Figure 1, which is proportional to the pathlength difference between the Michelson interferometer arms, so that a longer distance would increase the resolution (Gauglitz and Vo-Dihn, 2003). More precisely, the limiting factor to achieve even higher resolution with modern FTIR instruments is the precision of the optic and movement mechanisms for the moving mirrors in the interferometer (Stuart, 2005).

\section{Analysis of foods adulteration and authenticity using FTIR}

\section{Foods analysed by FTIR}

Traditionally, FTIR has been used to detect food adulteration in virgin oil (Rohman and Man, 2010; Georgouli, Martinez Del Rincon and Koidis, 2017b ), honey (Rios-Corripio et al., 2011; Gok et al., 2015) and beef (Alamprese et al., 2013; Nunes et al., 2016b). However, recently it has also been used to analyse adulteration and authenticity in spices and herbs, such as saffron and oregano (Black et al., 2016; Lohumi et al., 2017b; Petrakis and Polissiou, 2017; Wielogorska et al., 2018), authenticity of wine and wine based products (Cozzolino et al., 2009b; Ríos-Reina et al., 2017) and nectars and jams (Miaw et al., 2018). All in all, IR spectroscopy has been used to detect fraud of many of the food products listed as most at risk (Hoffman, 2013b), emphasising the effectiveness of FTIR analysis in the battle against EMA and authenticity frauds. 
Analysis of solid foods in FTIR can be carried out using alkali halide discs made from potassium bromide $(\mathrm{KBr})$, as this simple inorganic salt do not generate any vibrations in the MIR region (Nyquist and Kagel, 2012). Solid materials can therefore be analysed by mixing the analyte with $\mathrm{KBr}$ and subsequently pressing the mix to a fused disc which can be introduced into the light beam of a spectrophotometer (Simmons, 1960; Gauglitz and Vo-Dihn, 2003). The use of $\mathrm{KBr}$ discs is seemingly the preferred method in some studies, such as for the detection of fraud in saffron samples (Anastasaki et al., 2010; Ordoudi et al., 2017; Petrakis and Polissiou, 2017), see Table 1. One of the main disadvantages by using $\mathrm{KBr}$ discs is the issue of reproducibility, as conditions such as matrix ratios and homogeneousness needs to be exactly the same for each sample. Even with the addition of internal standards, the discs and mulls must be prepared under precisely the same circumstances to avoid any changes in path length and thus response (Stuart, 2005). Moreover, $\mathrm{KBr}$ pellet method is susceptible to interfering moisture effects, that may cause water absorption peaks in the infrared spectrum or fluctuations in the baseline due to scattering caused by the clouding of $\mathrm{KBr}$ pellets (Stuart, 2005). Furthermore, due to the mixing of analyte and $\mathrm{KBr}$ this sample preparation technique is destructive. nowadays when investigating food authenticity or adulteration, most likely due to its minimal, sometimes non-existent, sample preparation. In ATR FTIR the sample is pressed against a crystal, usually made from germanium, diamond or zinc selenide (Gauglitz and Vo-Dihn, 2003). The technique operates by measuring the changes that occur in a internally reflected IR beam when the it comes into contact with a sample surface (see Figure 2) (Kazarian and Chan, 2013). When the IR beam travels inside the crystal a standing wave of radiation, called the evanescent wave, is created (Gauglitz and VoDihn, 2003). ATR has in recent years revolutionised solid and liquid sample analyses by FTIR as it combats the most challenging aspects of infrared analyses, namely sample preparation and spectral reproducibility (Kazarian and Chan, 2013), thus increasing the reproducibility of the analyses. This method does not only minimise issues with reproducibility it also allows for a rapid analysis. As with any screening technique, ATR also has its limitations, caused by the optical contact between the sample 

crystal surface and apply pressure (Lindenberg et al., 2012).

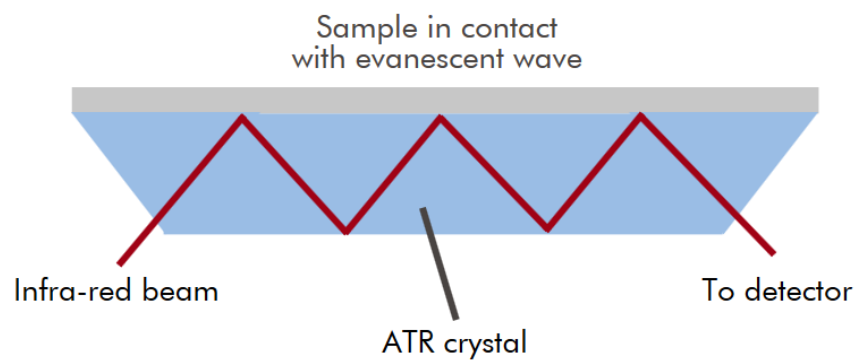

Figure 2. Schematics of an Attenuated total reflectance (ATR) cell.

\section{Multivariate analysis of FTIR results}

313

Two of the most common multivariate analyses employed for the quantification of adulteration is partial least squares (PLS) and principal component regression (PCR). These statistical techniques are normally used for calibration purposes and uses the full spectra region rather than smaller region of prespecified wave numbers (Tasumi, 2015). Both these methods also use statistically independent covariates from lower dimensions (Granato and Ares, 2014). The main difference between PLS and PCR is that while PCR seeks a high variance distance between the space of the covariates, PLS seeks the space between covariates that will predict the best outcome, using the concentration information (Tasumi, 2015). To establish calibration curves, PLS is therefore more suitable for analysing noisy spectra when the noise is random, whereas PCR is more appropriate for spectra where a systematic noise is observed (Tasumi, 2015).

Another statistical approach, particularly employed for screening purposes, is principal component analysis (PCA) which is an exploratory method (Rios-Corripio et al., 2011; Jaiswal et al., 2015a; Ríos-Reina et al., 2017). The aim of a PCA is to depict as much variability in a data set, such as an IR spectra, using as few variables as possible (Currell, 2015) and a linear combination of the original variables is used to generate new variables (Callao and Ruisánchez, 2018). The output of a PCA can then be visualised in a score plot, where the position of each sample is positioned according to its values 
of the principal components (PCs), centralised around zero (Currell, 2015). A PCA approach is typically used to visualise the difference between suspected adulterated foods and pure foods, with the expectation that the two should for separate clusters in the resulting scatter plot. However, a major drawback of PCA is that this method generates PCs in an unsupervised manner (Vidal, Ma and Sastry, 2016). This unsupervised learning means that there is not a specifically predicted target variable, which is commonly used for find general patterns in the data set (Cady, 2017).

There is however, supervised classification techniques which aims to individually assign unknown samples to a predefined class based on sample characteristics (Callao and Ruisánchez, 2018). Examples of classification techniques commonly used for food fraud investigations are linear discriminant analysis (LDA), $\mathrm{k}$ nearest neighbours $(\mathrm{kNN})$ and partial least squares discriminant analysis (PLS-DA), see Table 1. These techniques all require at least two defined classes, and will classify unknown samples to the class it most closely resembles based on a set of characteristics (Callao and Ruisánchez, 2018). However, a major drawback of these statistical methods is the need to add known adulterants to authentic foods when building the model, which means that they are not suitable for nontarget analyses. Moreover, the detection of outliers within a dataset is more difficult using these methods, as all samples are assigned to a class (Currell, 2015; Callao and Ruisánchez, 2018).

Due to the drawback with both unsupervised and classification methods soft supervised learning models, such as Soft Independent Modeling Class Analogy (SIMCA), has in recent years gained attention for analysing suspected adulteration of food, see Table 1. In a SIMCA, the classification is made based on a set of PCs from training data, such as a calibration set (Salzer and Siesler, 2014). These classes are then applied on test data, where a class is independently assigned to the test data based on the closeness of that data to the classes in a multidimensional space (Salzer and Siesler, 2014; Callao and Ruisánchez, 2018). SIMCA has especially been shown to be useful when comparing known adulterated samples with unknown samples (Santos, Pereira-Filho and RodriguezSaona, 2013; Li et al., 2015; Black et al., 2016). As SIMCA only classifies the sample in one class, it is more suitable for cases where the adulterant is not known, and only the adulterated class needs to be 
defined (Callao and Ruisánchez, 2018). However, due to this one class assignment the results can sometimes be ambiguous or inconclusive (Callao and Ruisánchez, 2018). Moreover, some studies using FTIR to detect food adulteration have presented novel statistical tools, such as Continuous Locality Preserving Projections (CLPP) in recent years (Georgouli, Martinez Del Rincon and Koidis, 2017b) and hierarchical models (HM) (Gok et al., 2015; Reis et al., 2017) in recent years, to detect food adulteration based on FTIR data. CLPP can model mixtures of food and adulterant as data series rather than discrete data points, thus enabling a better visualisation of the classification compared to a PCA (Georgouli, Martinez Del Rincon and Koidis, 2017b). Just as PLS or PCR, HM is a type of linear regression model. However, in HM the variables fall into strictly hierarchical levels, also known as nested levels (Kery and Royle, 2016). Although HM has traditionally been used in biology to describe biodiversity (Kery and Royle, 2016), it can be used to classify nonadulterated versus adulterated food and even identify which particular adulterant has been used (Reis et al., 2017). However, to be able to identify the specific adulterant it must be used when building the model, and thus HM is not suitable for non-target analysis. 


\begin{tabular}{|c|c|c|c|c|c|c|c|}
\hline Food & Adulterants & Determining adulteration & $\begin{array}{l}\text { Sampling } \\
\text { technique }\end{array}$ & $\begin{array}{c}\text { FTIR } \\
\text { wavelengths }\end{array}$ & Multivariate model & Comments & Study \\
\hline \multirow{3}{*}{ Honey } & $\begin{array}{c}\text { Different } \\
\text { Anatolian honey } \\
\text { samples } \\
\end{array}$ & N/A & ATR & $\begin{array}{l}\text { Mid-IR }(1800- \\
\left.750 \mathrm{~cm}^{-1}\right)\end{array}$ & $\begin{array}{l}\text { Hierarchical clustering } \\
\text { and PCA }\end{array}$ & $\begin{array}{l}\text { Developed method able to } \\
\text { differentiate between honey } \\
\text { floral source }\end{array}$ & (Gok et al., 2015) \\
\hline & $\begin{array}{l}\text { Inverted beet } \\
\text { sugar adulteration }\end{array}$ & $\begin{array}{l}\text { Scanned multiple samples of honey } \\
\text { with different concentrations of } \\
\text { beet invert sugar }(0.5 \text { to } 25 \% \mathrm{w} / \mathrm{w})\end{array}$ & ATR & $\begin{array}{l}\text { Mid-IR }(950- \\
\left.1500 \mathrm{~cm}^{-1}\right)\end{array}$ & PLS and PCR & $\begin{array}{l}88-94 \% \text { of the validation set } \\
\text { were classified correctly }\end{array}$ & $\begin{array}{l}\text { (Sivakesava and Irudayaraj, } \\
\text { 2001) }\end{array}$ \\
\hline & $\begin{array}{l}\text { Corn syrup, cane } \\
\text { sugar syrup }\end{array}$ & $\begin{array}{l}\text { Honey samples from central } \\
\text { Mexico were adulterated }(0-90 \%)\end{array}$ & ATR & $\begin{array}{l}\text { Mid -IR (900- } \\
\left.1140 \mathrm{~cm}^{-1}\right)\end{array}$ & PCA & $\begin{array}{l}\text { Method able to discriminate } \\
\text { between honey and cheaper } \\
\text { syrup. }\end{array}$ & (Rios-Corripio et al., 2011) \\
\hline \multirow{6}{*}{ Olive oil } & $\begin{array}{l}\text { Sunflower oil, } \\
\text { corn oil, and } \\
\text { canola oil }\end{array}$ & $\begin{array}{l}\text { Extra virgin olive oil was } \\
\text { adulterated with varying } \\
\text { concentrations of palm oil }(1.0- \\
50.0 \% \text { wt./wt) }\end{array}$ & ATR & $\begin{array}{l}\text { Mid - IR (1500- } \\
\quad 1000 \mathrm{~cm}^{-1)}\end{array}$ & PLS and PCR & $\begin{array}{l}\text { Developed method able to } \\
\text { discriminate between extra } \\
\text { virgin olive oil and the } \\
\text { adulterants tested }\end{array}$ & (Rohman and Man, 2010) \\
\hline & N/A & $\begin{array}{l}47 \text { samples of extra virgin olive oil } \\
\text { from both PDOs and other origins } \\
\text { were analysed }\end{array}$ & ATR & $\begin{array}{l}\text { Mid -IR (4000- } \\
\left.630 \mathrm{~cm}^{-1}\right) \\
\text { NIR }(10,000- \\
\left.4000 \mathrm{~cm}^{-1}\right)\end{array}$ & PLS-DA and SIMCA & $\begin{array}{l}\text { NIR was found to provide } \\
\text { better predictions than MIR, } \\
\text { year of harvest were found to } \\
\text { impact on spectra }\end{array}$ & (Bevilacqua et al., 2012b) \\
\hline & N/A & $\begin{array}{l}\text { Monovarietal extra virgin olive } \\
\text { oils from three cultivars } \\
\text { (Portuguese) }\end{array}$ & ATR & $\begin{array}{c}\text { Mid - IR }(700- \\
740,950-1050, \\
1100-1250, \\
1350-1500, \\
1700-1800 \text { and } \\
\left.2750-3000 \mathrm{~cm}^{-1}\right)\end{array}$ & PLS-DA and PCA & $\begin{array}{l}\text { PLS-DA able to discriminate } \\
\text { between samples from the } \\
\text { three different cultivars }\end{array}$ & (Gouvinhas et al., 2015) \\
\hline & $\begin{array}{l}\text { Sunflower, corn, } \\
\text { soybean and } \\
\text { hazelnut }\end{array}$ & $\begin{array}{l}\text { Extra virgin olive oil samples were } \\
\text { adulterated }(0 \%, 5 \%, 10 \%, 30 \% \text {, } \\
50 \%, 75 \% \text { and } 100 \%)\end{array}$ & $\mathrm{KBr}$ discs & $\begin{array}{l}\text { Mid -IR (4000- } \\
\left.500 \mathrm{~cm}^{-1}\right)\end{array}$ & LDA & $\begin{array}{l}\text { Adulterant levels down to 5\% } \\
\text { could be detected using the } \\
\text { method developed }\end{array}$ & (Lerma-García et al., 2010) \\
\hline & Hazelnut oil & $\begin{array}{l}\text { Four extra virgin olive oil samples } \\
\text { with different origins were } \\
\text { adulterated with hazelnut oil (1- } \\
90 \%)\end{array}$ & ATR & $\begin{array}{l}\text { Mid - IR (4000- } \\
\left.\quad 550 \mathrm{~cm}^{-1}\right)\end{array}$ & CLPP & $\begin{array}{l}\text { Method developed can be used } \\
\text { for screening purposes on even } \\
\text { low levels of adulteration } \\
(1 \%) \text {. Raman spectroscopy } \\
\text { also investigated. }\end{array}$ & $\begin{array}{l}\text { (Georgouli, Martinez Del } \\
\text { Rincon and Koidis, 2017b) }\end{array}$ \\
\hline & $\begin{array}{l}\text { Canola, hazelnut, } \\
\text { pomace and high } \\
\text { linoleic/oleic } \\
\text { sunflower }\end{array}$ & $\begin{array}{l}\text { Extra virgin olive oil was } \\
\text { adulterated with varying } \\
\text { concentrations of adulterating oil } \\
(5-40.0 \% \text { wt./wt) }\end{array}$ & ATR & $\begin{array}{l}\text { Mid - IR (4000- } \\
\quad 700 \mathrm{~cm}^{-1)}\end{array}$ & PLS & $\begin{array}{l}\text { Method developed were able } \\
\text { to discriminate between olive } \\
\text { oil and adulterants and } \\
\text { determine level of adulteration }\end{array}$ & (Maggio et al., 2010) \\
\hline
\end{tabular}




\begin{tabular}{|c|c|c|c|c|c|c|c|}
\hline \multirow{4}{*}{ Beef } & $\begin{array}{l}\text { Injecting solutions } \\
\text { of non-meat } \\
\text { ingredients }(\mathrm{NaCl}, \\
\text { phosphates, } \\
\text { carrageenan, } \\
\text { maltodextrin) }\end{array}$ & $\begin{array}{l}\text { Seized meat products from five } \\
\text { slaughterhouses were analysed }\end{array}$ & ATR & $\begin{array}{l}\text { Mid-IR (4000 to } \\
\left.525 \mathrm{~cm}^{-1}\right)\end{array}$ & $\begin{array}{l}\text { Classification PLS-DA } \\
\text { models }\end{array}$ & $\begin{array}{l}\text { The addition of addition } \mathrm{NaCl} \\
\text { to bovine meat causes specific } \\
\beta \text {-sheets vibrations of proteins }\end{array}$ & (Nunes et al., 2016b) \\
\hline & Pork & $\begin{array}{l}\text { Analysis of fats from pork and beef } \\
\text { mince meat }\end{array}$ & ATR & $\begin{array}{c}\text { Mid -IR (1200- } \\
1000 \mathrm{~cm}^{-1)}\end{array}$ & PLS & $\begin{array}{l}\text { Method able to quantify pork } \\
\text { traces in beef meatballs }\end{array}$ & (Rohman et al., 2011) \\
\hline & Turkey mince & $\begin{array}{l}\text { Minced beef adulterated with } \\
\text { turkey meat }(5-50 \% \mathrm{w} / \mathrm{w})\end{array}$ & ATR & $\begin{array}{l}\text { Mid-IR }(4000- \\
\left.\quad 400 \mathrm{~cm}^{-1}\right)\end{array}$ & PCA, LDA, and PLS & $\begin{array}{l}\text { Combining information from } \\
\text { UV/vis, NIR and MIR } \\
\text { spectroscopy improved the } \\
\text { confidence in the results }\end{array}$ & (Alamprese et al., 2013) \\
\hline & $\begin{array}{l}\text { Horse meat, fat } \\
\text { beef trimmings, } \\
\text { and textured soy } \\
\text { protein }\end{array}$ & $\begin{array}{l}\text { Mixtures of beef minced meat and } \\
\text { the adulterants were prepared ( } 2- \\
90 \%(\mathrm{w} / \mathrm{w}))\end{array}$ & ATR & $\begin{array}{l}\text { Mid-IR }(4000- \\
\left.\quad 650 \mathrm{~cm}^{-1}\right)\end{array}$ & PCR and SIMCA & $\begin{array}{l}\text { Method able to identify and } \\
\text { quantify adulterant }\end{array}$ & $\begin{array}{l}\text { (Meza-Márquez, Gallardo- } \\
\text { Velázquez and Osorio-Revilla, } \\
\text { 2010) }\end{array}$ \\
\hline \multirow{3}{*}{ Saffron } & $\begin{array}{l}\text { Six characteristic } \\
\text { adulterants of } \\
\text { plant origin, i.e. } \\
\text { C. sativus } \\
\text { stamens, } \\
\text { calendula, } \\
\text { safflower, } \\
\text { turmeric, } \\
\text { buddleia, and } \\
\text { gardenia }\end{array}$ & $\begin{array}{l}\text { Saffron was adulterated with } \\
\text { adulterants }(5-20 \% \text { w/w })\end{array}$ & & $\begin{array}{l}\text { Mid-IR }(4000- \\
\left.600 \mathrm{~cm}^{-1}\right)\end{array}$ & PCA and PLS-DA & $\begin{array}{l}\text { Proposed method involved a } \\
\text { three-step process for the } \\
\text { detection of adulteration as } \\
\text { well as for the identification } \\
\text { and quantification of } \\
\text { adulterants }\end{array}$ & (Petrakis and Polissiou, 2017) \\
\hline & $\begin{array}{l}\text { Tartrazine, } \\
\text { sunset yellow } \\
\text { along with } \\
\text { propane-1,2- } \\
\text { diol, propan-2- } \\
\text { ol and } \\
\text { acylglycerols }\end{array}$ & $\begin{array}{l}\text { Synthetic commercial sample } \\
\text { tested that mimicked the } \\
\text { appearance and specific UV- } \\
\text { Vis absorbance values of trade } \\
\text { standard test }\end{array}$ & $\mathrm{KBr}$ & $\begin{array}{l}\text { Mid-IR }(4000- \\
\left.\quad 400 \mathrm{~cm}^{-1}\right)\end{array}$ & Linear regression & $\begin{array}{l}\text { Multistep workflow using data } \\
\text { acquired from HPLC-UV/Vis, } \\
\text { UV-Vis, mid-infrared (FTIR) } \\
\text { and nuclear magnetic } \\
\text { resonance } \\
\text { (NMR) }\end{array}$ & (Ordoudi et al., 2017) \\
\hline & N/A & $\begin{array}{l}\text { Saffron from four countries, } \\
\text { including from the region of } \\
\text { Castilla- La Mancha }\end{array}$ & $\mathrm{KBr}$ discs & $\begin{array}{l}\text { Mid-IR }(4000- \\
\left.\quad 400 \mathrm{~cm}^{-1}\right)\end{array}$ & PCA and DA & $\begin{array}{l}\text { Method able to correctly } \\
\text { classify saffron from different } \\
\text { countries in } 90-98 \% \text { of the } \\
\text { cases depending on origin }\end{array}$ & (Anastasaki et al., 2010) \\
\hline
\end{tabular}




\begin{tabular}{|c|c|c|c|c|c|c|c|}
\hline & $\begin{array}{l}\text { Calendula flowers } \\
\text { or ground } \\
\text { turmeric }\end{array}$ & $\begin{array}{l}\text { Quantification of crocin in the } \\
\text { samples }\end{array}$ & ATR & $\begin{array}{l}\text { Mid-IR }(1700- \\
\left.\quad 900 \mathrm{~cm}^{-1}\right)\end{array}$ & Target analysis, PLS & $\begin{array}{l}\text { Validated against UV-Vis } \\
\text { standard (ISO/TS3632) }\end{array}$ & $\begin{array}{l}\text { (Lee, Htar and Akowuah, } \\
\text { 2015) }\end{array}$ \\
\hline \multirow{3}{*}{ Milk } & $\begin{array}{l}\text { Whey, hydrogen } \\
\text { peroxide, } \\
\text { synthetic urine, } \\
\text { urea and synthetic } \\
\text { milk }\end{array}$ & $\begin{array}{l}\text { Milk was spiked with each of the } \\
\text { adulterant at five different levels }\end{array}$ & ATR & $\begin{array}{l}\text { Mid-IR }(1400- \\
\left.1800 \mathrm{~cm}^{-1}\right)\end{array}$ & SMCA and PLS & $\begin{array}{l}\text { Method able to discriminated } \\
\text { samples based on levels of } \\
\text { adulteration, and also type of } \\
\text { adulterant }\end{array}$ & $\begin{array}{l}\text { (Santos, Pereira-Filho and } \\
\text { Rodriguez-Saona, 2013) }\end{array}$ \\
\hline & Soymilk & $\begin{array}{l}\text { Milk samples were adulterated } \\
\text { with soymilk }(2-40 \%)\end{array}$ & ATR & $\begin{array}{c}\text { Mid-IR }(4000- \\
500 \mathrm{~cm}^{-} \text {and } \\
1680-1058 \\
\left.\mathrm{~cm}^{-1}\right) \\
\end{array}$ & PCA & $\begin{array}{l}\text { Method able to identify and } \\
\text { quantify adulterant in ranges } \\
\text { tested }\end{array}$ & (Jaiswal et al., 2015b) \\
\hline & Melamine & $\begin{array}{l}\text { Milk samples were adulterated } \\
\text { with melamine }(0.0625-25 \% \text { w/w) }\end{array}$ & ATR & $\begin{array}{l}\text { Mid-IR }(4000- \\
\left.\quad 650 \mathrm{~cm}^{-1}\right)\end{array}$ & & $\begin{array}{l}\text { Developed method able to } \\
\text { distinguish between } \\
\text { unadulterated milk samples } \\
\text { and that containing } 2.5 \mathrm{ppm} \\
\text { MEL (threshold) }\end{array}$ & (Jawaid et al., 2013) \\
\hline \multirow{3}{*}{ Butter } & Margarine & $\begin{array}{l}\text { Butter was mixed with margarine } \\
(0-100 \% \mathrm{w} / \mathrm{w})\end{array}$ & ATR & $\begin{array}{l}\text { Mid-IR (900- } \\
1800 \text { and } 2800- \\
\left.3040 \mathrm{~cm}^{-1}\right)\end{array}$ & PLS & $\begin{array}{l}\text { Method able to predict } \\
\text { adulteration with high } \\
\text { confidence in selected } \\
\text { adulteration ranges (0-5\%,0- } \\
25 \% \text { and } 20-60 \%)\end{array}$ & (Koca et al., 2010) \\
\hline & $\begin{array}{l}\text { Cheap animal fats; } \\
\text { Lard }\end{array}$ & $\begin{array}{l}\text { Butter adulterated with lard } \\
\qquad(0.5-80 \%)\end{array}$ & & $\begin{array}{l}\text { Mid-IR }(4000- \\
\left.650 \mathrm{~cm}^{-1}\right)\end{array}$ & PLS & $\begin{array}{l}\text { Method determined for rapid } \\
\text { identification of adulteration of } \\
\text { butter with lard }\end{array}$ & (Nurrulhidayah et al., 2015) \\
\hline & N/A & $\begin{array}{l}\text { In total, } 54 \text { unsalted butter samples } \\
\text { from three different regions of } \\
\text { Morocco were tested }\end{array}$ & ATR & $\begin{array}{l}\text { Mid-IR (4000- } \\
\left.600 \mathrm{~cm}^{-1}\right)\end{array}$ & PCA, PLS and PLS-DA & $\begin{array}{l}\text { PLS-DA were able to } \\
\text { discriminate accurately } \\
\text { between butter samples from } \\
\text { the three different regions }\end{array}$ & (Bassbasi et al., 2014) \\
\hline Cheese & Formaldehyde & $\begin{array}{l}\text { Soft white cheese were spiked with } \\
\text { formaldehyde }(1-100 \mathrm{mg} / 100 \mathrm{~g})\end{array}$ & ATR & $\begin{array}{l}\text { Mid-IR }(1600- \\
\left.\quad 850 \mathrm{~cm}^{-1}\right)\end{array}$ & PLS & $\begin{array}{l}\text { Method developed suitable for } \\
\text { determination of } \\
\text { formaldehyde/formalin in } \\
\text { cheese samples }\end{array}$ & (Alkhalf and Mirghani, 2017) \\
\hline Oregano & $\begin{array}{l}\text { Myrtle, olive } \\
\text { leaves }\end{array}$ & $\begin{array}{l}\text { Mixtures of oregano and each } \\
\text { adulterant were prepared }(0-100 \% \\
\text { w/w) }\end{array}$ & ATR & $\begin{array}{l}\text { Mid-IR }(4000- \\
\left.\quad 550 \mathrm{~cm}^{-1}\right)\end{array}$ & PLS and SIMCA & $\begin{array}{l}\text { Liquid Chromatography High } \\
\text { Resolution Mass spectrometry } \\
\text { (LC-HRMS) to confirm } \\
\text { oregano adulteration using } \\
\text { biomarkers }\end{array}$ & $\begin{array}{l}\text { (Black et al., 2016; } \\
\text { Wielogorska } \text { et al., 2018) }\end{array}$ \\
\hline
\end{tabular}




\begin{tabular}{|c|c|c|c|c|c|c|c|}
\hline $\begin{array}{l}\text { Paprika and } \\
\text { chili powder }\end{array}$ & Sudan dye & $\begin{array}{l}\text { Paprika powder were adulterated ( } \\
0.02,-0.6 \% \mathrm{w} / \mathrm{w} \text { ) }\end{array}$ & ATR & $\begin{array}{l}\text { Mid-IR }(1400- \\
\left.1800 \mathrm{~cm}^{-1}\right)\end{array}$ & $\begin{array}{l}\mathrm{HLA} / \mathrm{GO} \text { (hybrid linear } \\
\text { analysis) }\end{array}$ & $\begin{array}{l}\text { Technique determined to be } \\
\text { cost-effective in comparison to } \\
\text { main alternative technique, } \\
\text { LC. }\end{array}$ & (Lohumi et al., 2017b) \\
\hline Onion powder & Starch & $\begin{array}{l}\text { Samples were adulterated with } \\
\text { starch }(1-35 \% \mathrm{w} / \mathrm{w})\end{array}$ & ATR & $\begin{array}{c}\text { Mid-IR }(4000- \\
\left.650 \mathrm{~cm}^{-1}\right), \text { Near- } \\
\text { IR }(10000-4000 \\
\left.\mathrm{cm}^{-1}\right)\end{array}$ & PLS & $\begin{array}{l}\text { FT-NIR data was determined } \\
\text { to have a higher predictive } \\
\text { value than FTIR }\end{array}$ & (Lohumi et al., 2014) \\
\hline Coffee & $\begin{array}{l}\text { Spent coffee } \\
\text { grounds, roasted } \\
\text { coffee husks, } \\
\text { roasted corn, and } \\
\text { roasted barley }\end{array}$ & $\begin{array}{l}\text { Coffee adulterated with single or } \\
\text { mixed adulterant (33.3-99\% coffee } \\
\text { in samples) }\end{array}$ & $\begin{array}{l}\text { ATR and } \\
\text { diffuse } \\
\text { reflectance, } \\
\text { DR }\end{array}$ & $\begin{array}{l}\text { Mid-IR }(4000- \\
\left.550 \mathrm{~cm}^{-1}\right)\end{array}$ & $\mathrm{HM}$ and $\mathrm{DF}$ & $\begin{array}{l}\text { Method able to identifying } \\
\text { adulterants in coffee, even in } \\
\text { complex mixtures. }\end{array}$ & (Reis et al., 2017) \\
\hline $\begin{array}{l}\text { Java tea } \\
\text { (Orthosiphon } \\
\text { stamineus) }\end{array}$ & N/A & $\begin{array}{l}\text { Samples were tested based on their } \\
\text { geographical origin and examined } \\
\text { for a characteristic infrared } \\
\text { spectrum }\end{array}$ & $\mathrm{KBr}$ discs & $\begin{array}{l}\text { Mid-IR }(4000- \\
\left.\quad 550 \mathrm{~cm}^{-1}\right)\end{array}$ & PLS and SIMCA & $\begin{array}{l}\text { Sample origin seems to have } \\
\text { more dominant effect to the } \\
\text { chemical constituent of the } \\
\text { plant compared to plant } \\
\text { varieties }\end{array}$ & (Sim et al., 2004) \\
\hline $\begin{array}{l}\text { Organic wine } \\
\text { (Australian) }\end{array}$ & $\begin{array}{l}\text { Non-organic wine } \\
\quad \text { (Australian) }\end{array}$ & $\begin{array}{l}\text { Organic and non-organic wines } \\
(\mathrm{n}=172) \text { from eight different wine } \\
\text { varieties, thirteen regions of } \\
\text { Australia and vintages ranging } \\
\text { from 200-2008 were analysed }\end{array}$ & $\begin{array}{l}\text { Bacchus flow } \\
\text { cell }\end{array}$ & $\begin{array}{l}\text { Mid-IR (4000- } \\
\left.400 \mathrm{~cm}^{-1}\right)\end{array}$ & $\begin{array}{l}\text { PCA, discriminant PLS } \\
\text { and LDA }\end{array}$ & $\begin{array}{l}\text { DPLS was able to correctly } \\
\text { assign } 85 \% \text { of all samples }\end{array}$ & (Cozzolino et al., 2009a) \\
\hline $\begin{array}{l}\text { Wine vinegars } \\
\quad \text { (PDO) }\end{array}$ & N/A & $\begin{array}{l}\text { In total } 67 \text { different wine vinegars } \\
\text { belonging to different PDO } \\
\text { categories were tested }\end{array}$ & ATR & $\begin{array}{l}\text { Mid-IR (1800- } \\
900 \mathrm{~cm}^{-1}\end{array}$ & PLS and PCA & $\begin{array}{l}\text { Method able to distinguish } \\
\text { between different wine } \\
\text { vinegars aged different times }\end{array}$ & (Ríos-Reina et al., 2017) \\
\hline Walnut oil & Soybean oil & $\begin{array}{l}\text { Four types of walnut oil was } \\
\text { adulterated with three types of } \\
\text { soybean oil }(5-50 \%, \mathrm{v} / \mathrm{v})\end{array}$ & ATR & $\begin{array}{l}\text { Mid -IR (4000- } \\
\left.650 \mathrm{~cm}^{-1}\right)\end{array}$ & PLS and SIMCA & $\begin{array}{l}\text { Method could determine } \\
\text { adulteration by soybean oil } \\
\text { down to } 10 \%\end{array}$ & (Li et al., 2015) \\
\hline Avocado oil & $\begin{array}{l}\text { Sunflower, canola } \\
\text { and soybean oils }\end{array}$ & $\begin{array}{l}\text { Mixtures of avocado oil and each } \\
\text { adulterant were prepared (range } \\
\text { between 2-50\%) (v:v) }\end{array}$ & ATR & $\begin{array}{l}\text { Mid-IR (4000- } \\
550 \mathrm{~cm}-1)\end{array}$ & PLS and SIMCA & $\begin{array}{l}\text { Developed method gave } \\
\text { standard errors of prediction } \\
\text { between } 0.09 \text { and } 2.81 \text { for the } \\
\text { adulteration }\end{array}$ & (Quiñones-Islas et al., 2013) \\
\hline $\begin{array}{l}\text { Nectars } \\
\text { (Grape, } \\
\text { orange, peach } \\
\text { and passion } \\
\text { fruit) } \\
\end{array}$ & $\begin{array}{l}\text { Syrup, apple } \\
\text { and cashew juices }\end{array}$ & $\begin{array}{l}\text { Nectars were adulterated according } \\
\text { to a complex scheme }\end{array}$ & ATR & $\begin{array}{l}\text { Mid -IR (4000- } \\
\left.650 \mathrm{~cm}^{-1}\right)\end{array}$ & PLS & $\begin{array}{l}\text { The mean relative errors of } \\
\text { prediction using developed } \\
\text { model varied from } 3.0 \text { to } 6.7 \%\end{array}$ & (Miaw et al., 2018) \\
\hline $\begin{array}{l}\text { Jams and } \\
\text { juices }\end{array}$ & $\begin{array}{l}\text { Glucose syrup, } \\
\text { synthetic flavour }\end{array}$ & $\begin{array}{l}\text { Jams from fruits were prepared } \\
\text { using } 100 \% \text { sucrose, } 50 \% \text { sucrose }\end{array}$ & $\mathrm{KBr}$ discs & $\begin{array}{l}\text { Mid -IR (4000- } \\
\left.400 \mathrm{~cm}^{-1}\right)\end{array}$ & Analysis of variance & $\begin{array}{l}\text { Developed method able to } \\
\text { distinguish adulterated jams }\end{array}$ & (Mohamed et al., 2011) \\
\hline
\end{tabular}




\begin{tabular}{|c|l|l|l|l|l|l|}
\hline $\begin{array}{c}\text { (strawberry } \\
\text { and apricot } \\
\text { jam, orange, } \\
\text { apple and } \\
\text { strawberry } \\
\text { juices) }\end{array}$ & $\begin{array}{l}\text { and pigment } \\
\text { (allura red and } \\
\text { sunset yellow) }\end{array}$ & $\begin{array}{l}\text { and 50\% glucose syrup and 100\% } \\
\text { glucose syrup. Juices were } \\
\text { prepared from fruits }\end{array}$ & $\begin{array}{l}\text { and juices from non- } \\
\text { adulterated ones }\end{array}$ & & \\
\hline Tea & Talcum powder & $\begin{array}{l}210 \text { samples of tea powder with 13 } \\
\text { dose levels of talcum powder } \\
\left(0.15-1.40 \mathrm{mg} \mathrm{g}^{-1}\right)\end{array}$ & KBr discs & $\begin{array}{c}\text { Mid - IR (990- } \\
\left.1055 \mathrm{~cm}^{-1}\right)\end{array}$ & PCA & $\begin{array}{l}\text { Method developed able to } \\
\text { detect talcum powder in tea }\end{array}$ \\
(Li, Zhang and He, 2016)
\end{tabular}


371 Abbreviations: PCA: principal component analysis, PLS: partial least squares, PCR: principal component regression, PLS-DA: partial least squares discriminant analysis, SIMCA: Soft

372 Independent Modeling Class Analogy, LDA: linear discriminant analysis, CLPP: Continuous Locality Preserving Projection, HM: Hierarchical models and DF: data fusion 
374

375

Several studies have combined FTIR analysis with other analytical chemical techniques such as UVVis, near-IR (NIR) or Raman spectroscopy (Bevilacqua et al., 2012b; Alamprese et al., 2013; Lee, Htar and Akowuah, 2015; Georgouli, Martinez Del Rincon and Koidis, 2017a; Ordoudi et al., 2017), liquid chromatography coupled to either UV/Vis (Ordoudi et al., 2017) or high resolution mass spectrometry (LC-HRMS) detectors (Black et al., 2016; Wielogorska et al., 2018) and DNA barcoding (Wielogorska et al., 2018) in order to either compare a newly developed FTIR method with validated or standardised methods or to complement the FTIR analysis. For instance some studies have used FTIR analysis as a part of a spectroscopy test battery (Bevilacqua et al., 2012b; Alamprese et al., 2013; Georgouli, Martinez Del Rincon and Koidis, 2017a). Some of these studies have shown that combining FTIR with other spectroscopy techniques, such as UV-Vis and NIR, can improve the models for predicting adulteration of for example turkey mince in in beef (Alamprese et al., 2013). This was recently showcased in a case of saffron adulteration where the syntethic components used as adulterants were tailored to surpass the standard ISO 3632 testing solely relying on UV-Vis detection (Ordoudi et al., 2017). This further emphasises the need to use a combination of techniques in order to detect the increasing and more sophisticated cases of food fraud.

\section{FTIR in combination with other vibrational spectroscopy techniques}

Although there are similarities between NIR and MIR there are also important differences which affect the ability to detect some adulterants. In general, the intensity of NIR (NIR, 780-2500 nm) absorbance is much lower than MIR making it more difficult to detect (Sun, 2009). Additionally, specific chemical groups are difficult to associate with a specific IR frequency due to the weak, broad overtone and combination bands associated with NIR absorbance (Sun, 2009). NIR is also not as sensitive as MIR spectroscopy because its radiation will penetrate the sample to a greater extent compared to MIR (Sun, 2009). However, in some studies where onion powder and olive oil were analysed, NIR was found to give better predictions of adulteration than FTIR (Bevilacqua et al., 2012a; Lohumi et al., 2014). This can most likely be explained by the fact that NIR is better suited to analyse highly absorbing bulk samples, such as powders and liquids, due to the lower intensity of the NIR absorbance compared to 
MIR. FTIR has also been compared to Raman, specifically when the spectra were analysed using CLPP. For example Georgouli, Martinez Del Rincon and Koidis (2017) found that the prediction accuracy of adulteration of olive oil were similar between FTIR and Raman. One of the advantages of Raman compared to NIR and FTIR is that this type of spectroscopy does not exhibit interference from water, something that otherwise might be an issue when analysing foods without prior sample preparation.

\section{FTIR in combination with hyphenated mass spectrometry (MS) techniques}

Although FTIR analysis is a cheap and rapid screening technique that has been applied on many different food matrices, one drawback is that information regarding individual compounds or components in a complex mixture cannot be extracted. Therefore, it often needs to be complemented with other techniques such as hyphenated chromatography, for example LC coupled to high resolution MS (Black et al., 2016; Wielogorska et al., 2018) for confirmatory analyses in order to identify and quantify specific biomarkers, see Table 1. One advantage of combining FTIR with chromatography is that different compounds in a complex biological matrix such as foods, is first separated according to their physicochemical properties (Hird et al., 2014). Hyphenated to mass spectrometry this becomes very a powerful as the mass-to-charge ratio of ions is detected making it possible to provide both quantitative and structural information about the compounds in the sample (de Hoffman and Stroobant, 2007). However, one of the disadvantages of these HRMS methods are that the data analysis is often complex and laborious.

Using LC-HRMS for screening or non-target analyses is also an important technique in other areas of food safety, for instance for the screening of pesticides (García-Reyes et al., 2007; Malato et al., 2011; Gómez-Ramos et al., 2013), detection of contaminants in food packaging materials (Bengtström et al., 2016; Pérez-Ortega et al., 2016; Pieke, Smedsgaard and Granby, 2017) and identification of biomarkers for allergens (Korte, Lepski and Brockmeyer, 2016). With recent advances in non-target analysis of biomarkers in complex biological matrices using HRMS, it is expected that the two-tier approach using FTIR screening and LC-HRMS confirmation suggested by Black et al. (2016) and Wielogorska et al.(2018) for analyses of adulteration of oregano, will be implemented on a broader scale for analyses of food fraud. 
One of the major drawbacks with all analytical chemical techniques is that contamination by any other biological species, such as other species of ground plant material in spices or substituted minced meat, is not easily identifiable by chemical profiles alone. Novel interdisciplinary strategies combining analytical chemistry such as FTIR screening and HRMS identification of biomarkers, with molecular biology, such as that suggested for detecting adulterating oregano with olive and/or myrtle leaves suggested by Wielogorska et al. (2018). DNA techniques such as DNA barcoding, real-time polymerase chain reaction (PCR) and Sequence Characterised Amplified Region (SCAR) PCR have been extensively used to detect food adulteration in spices such as oregano (Marieschi et al., 2011b, 2011a), turmeric (Dhanya et al., 2011) and saffron (Marieschi, Torelli and Bruni, 2012; Villa et al., 2016) as well as meat products (Ali et al., 2015; Hou et al., 2015; Amaral et al., 2017).

However, these methods all require access to species specific sequence data in order to design suitable primers to be used in the amplification process, ensuring the amplification of the correct DNA molecule. One approach to remove this limitation is to use next generation sequencing (NGS). However, NGS is an expensive technique that often involves complex workflows, limiting its use in routine analysis (Burns et al., 2016). Although, these molecular methods are generally considered specific and sensitive they are still considered to be more qualitative than quantitative due to their high uncertainty in measurements (Burns et al., 2016). The sensitivity of these techniques means that even low level of accidental contamination can be analysed. However, due to the high level of quantitative uncertainty, even these low-level contaminations can be interpreted as intentional, and thus fraudulent (Galvin-King, Haughey and Elliott, 2018). 


\section{Conclusions}

449 The food production chain has become increasingly globalised, making food vulnerable to adulteration.

450 There is therefore a growing demand on both authorities and food producers to develop fast and efficient

451 methods for the comprehensive monitoring of food. Over the last decades, FTIR has proven itself to be

452 a powerful tool for screening of foods for adulteration and authenticity. It is a fast, easy and generally cost effective method to detect food adulteration and in some cases it can also provide information about the geographical origin of certain foods which can be useful for investigating of authenticity. In many cases, FTIR analysis in combination with multivariate data analysis is sufficient to predict the level of adulteration. However, for some purposes, the use of FTIR as part of an extended test battery, such as other spectroscopy techniques, hyphenated chromatographic methods or DNA analysis, is needed to confirm authenticity or quantitative adulteration. Developing test batteries employing several different analysis methods is highly desirable as there are an increasing number of reports where of adulterating agents have been designed to comply with certain standardised analyses. Thus the latest development in the fight against food fraud emphasise the need to use at minimum of two techniques, based on different chemical principles, as is already standard in other areas of forensic science.

Ideally, confirmatory analysis using hyphenated MS techniques or nuclear magnetic resonance (NMR) should be used to identify any biomarkers that could potentially be quantified. For instance, recent developments in tentative identification, i.e. identification without certified reference materials, by HRMS are promising for these purposes and recent studies have shown the large potential of this two-tier approach for screening and confirmation of cases of food fraud. This two-tier strategy should therefore be used to detect fraud of more groups of food, especially for groups where the fraud is suggested to become increasingly sophisticated. Furthermore, recent advances in DNA sequencing, such as technical advances in NGS and more powerful bioinformatics tools for downstream analyses, have the potential to identify adulteration down to the species level without prior sequence knowledge. This is particularly useful in the case of suspected adulteration of mincemeat and ground spices and herbs, as the potential to add virtually any meat or plant material to these foods without chemical detection is large. Information gained from the combined use of analytical chemistry and DNA analyses 
475 may even in certain cases be able used to trace the origin of any adulteration within the food supply 476 chain.

477 Food fraud by adulteration or authenticity is by no means a new phenomenon, but recent scandals 478 have illustrated the vulnerability of the modern and increasingly global food supply chain. Developing 479 rapid and easy screening techniques, using for instance FTIR, are therefore imperative to ensure future 480 food safety. With the increasing complexity of food fraud, future methods need to be able combine 481 rapid screening of large quantise of food as well as confirmatory analyses using for instance a 482 combination of detection techniques based on different chemical principles. 
Accum, F. (1820) A Treatise on Adulteration of Food and Culinary Poisons. Second edi. London, UK. Available at: https://publicdomainreview.org/collections/a-treatise-on-adulteration-of-food-andculinary-poisons-1820/.

Agres, T. (2015) The Cumin Scandal: Accidental or Fraudulent, Food Quality and Safety. Available at: http://www.foodqualityandsafety.com/article/the-cumin-scandal-accidental-orfraudulent/?singlepage $=1$ (Accessed: 12 June 2018).

Alamprese, C. et al. (2013) 'Detection of minced beef adulteration with turkey meat by UV-vis, NIR and MIR spectroscopy', LWT - Food Science and Technology. Elsevier Ltd, 53(1), pp. 225-232. doi: 10.1016/j.lwt.2013.01.027.

Albert, S., Albert, K. K. and Quack, M. (2011a) Handbook of High-resolution Spectroscopy. doi: 10.1002/9780470749593.

Albert, S., Albert, K. K. and Quack, M. (2011b) Handbook of High-resolution Spectroscopy. doi: 10.1002/9780470749593.

Ali, M. E. et al. (2015) 'Multiplex PCR assay for the detection of five meat species forbidden in Islamic foods', Food Chemistry. Elsevier Ltd, 177(2015), pp. 214-224. doi: 10.1016/j.foodchem.2014.12.098.

Alkhalf, M. I. and Mirghani, M. E. . (2017) 'Detection of formaldehyde in cheese using FTIR spectroscopy', International Food Research Journal, 24(December), pp. 496-500.

Amand, L. E. and Tullin, C. J. (1999) 'The Theory Behind FTIR analysis', Dep. of Energy Conversion, Chalmers University of Technology, Sweden, (0), pp. 1-15.

Amaral, J. S. et al. (2017) 'Quantitative detection of pork meat by EvaGreen real-time PCR to assess the authenticity of processed meat products', Food Control. Elsevier Ltd, 72, pp. 53-61. doi: 10.1016/j.foodcont.2016.07.029.

Amiry, S., Esmaiili, M. and Alizadeh, M. (2017) 'Classification of adulterated honeys by multivariate analysis’, Food Chemistry. Elsevier Ltd, 224, pp. 390-397. doi: 10.1016/j.foodchem.2016.12.025.

Anastasaki, E. et al. (2010) 'Differentiation of saffron from four countries by mid-infrared spectroscopy and multivariate analysis', European Food Research and Technology, 230(4), pp. 571577. doi: 10.1007/s00217-009-1197-7.

Añíbarro, B., Seoane, F. J. and Múgica, M. V. (2007) 'Involvement of hidden allergens in food 513 allergic reactions', Journal of Investigational Allergology and Clinical Immunology, 17(3), pp. 168514172.

Bassbasi, M. et al. (2014) 'Prediction of the geographical origin of butters by partial least square discriminant analysis (PLS-DA) applied to infrared spectroscopy (FTIR) data', Journal of Food Composition and Analysis. Elsevier Inc., 33(2), pp. 210-215. doi: 10.1016/j.jfca.2013.11.010.

Bawden, T. (2015) 'New Food Scandal over Peanuts is "More Serious" than the Horsemeat Crisis', The Independent, 13 February. Available at: https://www.independent.co.uk/life-style/food-anddrink/news/new-food-scandal-over-peanuts-is-more-serious-than-the-horsemeat-crisis10045725.html. 
Bengtström, L. et al. (2016) 'Non-targeted screening for contaminants in paper and board food contact materials using effect directed analysis and accurate mass spectrometry', Food Additives \& Contaminants: Part A, 0049(May), p. 19440049.2016.1184941. doi: 10.1080/19440049.2016.1184941.

Bevilacqua, M. et al. (2012a) 'Tracing the origin of extra virgin olive oils by infrared spectroscopy 10.1016/j.aca.2011.12.035.

Bevilacqua, M. et al. (2012b) 'Tracing the origin of extra virgin olive oils by infrared spectroscopy and chemometrics: A case study', Analytica Chimica Acta. Elsevier B.V., 717, pp. 39-51. doi: 10.1016/j.aca.2011.12.035.

Black, C. et al. (2016) 'A comprehensive strategy to detect the fraudulent adulteration of herbs: The oregano approach', Food Chemistry. The Authors, 210, pp. 551-557. doi: 10.1016/j.foodchem.2016.05.004.

Burns, M. et al. (2016) 'Measurement issues associated with quantitative molecular biology analysis of complex food matrices for the detection of food fraud', Analyst. Royal Society of Chemistry, 141(1), pp. 45-61. doi: 10.1039/c5an01392e.

540 Cady, F. (2017) The Data Science Handbook. Hoboken, New Jersey: John Wiley \& Sons Inc.

541 Callao, M. P. and Ruisánchez, I. (2018) 'An overview of multivariate qualitative methods for food 542 fraud detection', Food Control, 86, pp. 283-293. doi: 10.1016/j.foodcont.2017.11.034.

543 Chalmers, J. M. and Griffiths, P. R. (2002a) Handbook of Vibrational Spectroscopy. Theory and 544 Instrumentation. Volume 1, J. Am. Chem. Society. Chichester, UK: J. Wiley \& Sons. doi: $54510.1021 / \mathrm{ja} 025228 \mathrm{w}$.

Chalmers, J. M. and Griffiths, P. R. (2002b) Handbook of Vibrational Spectroscopy. Theory and Instrumentation. Volume 1, J. Am. Chem. Society. Chichester, UK: J. Wiley \& Sons. doi: $10.1021 / \mathrm{ja} 025228 \mathrm{w}$.

Cozzolino, D. et al. (2009a) 'Mid infrared spectroscopy and multivariate analysis: A tool to 550 discriminate between organic and non-organic wines grown in Australia', Food Chemistry. Elsevier 551 Ltd, 116(3), pp. 761-765. doi: 10.1016/j.foodchem.2009.03.022.

552 Cozzolino, D. et al. (2009b) 'Mid infrared spectroscopy and multivariate analysis: A tool to 553 discriminate between organic and non-organic wines grown in Australia', Food Chemistry. Elsevier 554 Ltd, 116(3), pp. 761-765. doi: 10.1016/j.foodchem.2009.03.022.

555 Currell, G. (2015) Scientific Data Analysis. Oxford, UK: Oxford University Press.

556 Dalmia, A. (2015) 'Rapid Measurement of Extra Virgin Olive Oil Adulteration with Olive Pomace 557 Oil with No Sample Preparation Using DSA / TOF', Perkin Elmer, pp. 3-6.

558 Defra et al. (2014) 'Elliott Review into the Integrity and Assurance of Food Supply Networks - Final 559 Report', British medical journal, 157(March), p. 146. doi: 10.1136/bmj.1.4348.621-a.

560 Department of Agriculture Food and and Marine, T. (2013) 'Equine DNA \& Mislabelling of

561 Processed Beef Investigation Report March 2013 Department of Agriculture, Food and the Marine', 562 (March), pp. 1-38. 
Dhanya, K. et al. (2011) 'Sequence characterized amplified region markers: A reliable tool for adulterant detection in turmeric powder', Food Research International. Elsevier Ltd, 44(9), pp. 28892895. doi: 10.1016/j.foodres.2011.06.040.

Downey, G. (2016) Advances in Food Authenticity Testing. Cambridge, UK.

Elliott, C. (2013) Elliott Review into the Integrity and Assurance of Food Supply Networks - interim report. Available at: https://www.gov.uk/government/publications.

Ellis, D. I. et al. (2012) 'Fingerprinting food: current technologies for the detection of food adulteration and contamination', Chemical Society Reviews, 41(17), p. 5706. doi: $10.1039 / \mathrm{c} 2 \mathrm{cs} 35138 \mathrm{~b}$.

ESA (2015) European Spice Association Quality Minima Document. Available at: https://www.esaspices.org/download/esa-qmd-rev-5-update-as-per-esa-tc-26-03-18.pdf.

European Comission (2018) Food Fraud. Available at: https://ec.europa.eu/food/safety/food-fraud_en (Accessed: 12 June 2018).

European Commission (2000) 'Directive 2000/13/EC on the approximation of the laws of the Member States relating to the labelling, presentation and advertising of foodstuffs', Official Journal of the European Union, 109(16), pp. 29-42. doi: 2004R0726 - v.7 of 05.06.2013.

European Commission (2002) 'Regulation (EC) 178/2002 of the European Parliament and of the Council of 28 January 2002 laying down the general principles and requirements of food law, establishing the European Food Safety Authority and laying down procedures in matters of food safety', Official Journal of the European Union, L 31, pp. 1-40. doi: 2004R0726 - v.7 of 05.06.2013.

European Commission (2018) European Commission - Food Fraud. Available at: https://ec.europa.eu/food/safety/food-fraud_en (Accessed: 29 August 2018).

Evershed, R. and Temple, N. (2016) Sorting the Beeffrom the Bull: The Science of Food Fraud Forensics. London, UK: Bloomsbury Publishing Inc.

FAO (2009) 'Global agriculture towards 2050', High Level Expert Forum-How to feed the world 2050, pp. 1-4. doi:

http://www.fao.org/fileadmin/templates/wsfs/docs/Issues_papers/HLEF2050_Global_Agriculture.pdf.

Food Standards Agency (2015) 'Adulteration of Food - Thresholds for Action and for', (November), pp. 1-7.

Galvin-King, P., Haughey, S. A. and Elliott, C. T. (2018) 'Herb and spice fraud; the drivers, challenges and detection', Food Control. Elsevier Ltd, 88, pp. 85-97. doi: 10.1016/j.foodcont.2017.12.031.

García-Reyes, J. F. et al. (2007) 'Comprehensive screening of target, non-target and unknown pesticides in food by LC-TOF-MS', TrAC - Trends in Analytical Chemistry, 26(8), pp. 828-841. doi: 10.1016/j.trac.2007.06.006.

Gauglitz, G. and Vo-Dihn, T. (2003) Handbook of Spectroscopy, Journal of the American Chemical Society. doi: 10.1021/ja033666c.

Georgouli, K., Martinez Del Rincon, J. and Koidis, A. (2017a) 'Continuous statistical modelling for rapid detection of adulteration of extra virgin olive oil using mid infrared and Raman spectroscopic data', Food Chemistry. Elsevier Ltd, 217, pp. 735-742. doi: 10.1016/j.foodchem.2016.09.011. 
Georgouli, K., Martinez Del Rincon, J. and Koidis, A. (2017b) 'Continuous statistical modelling for rapid detection of adulteration of extra virgin olive oil using mid infrared and Raman spectroscopic data', Food Chemistry. Elsevier Ltd, 217, pp. 735-742. doi: 10.1016/j.foodchem.2016.09.011.

GMA and Kearney, A. T. (2010) Consumer product Fraud: Deterrence and detection.

Gok, S. et al. (2015) 'Differentiation of Anatolian honey samples from different botanical origins by ATR-FTIR spectroscopy using multivariate analysis', Food Chemistry. Elsevier Ltd, 170, pp. 234240. doi: 10.1016/j.foodchem.2014.08.040.

Gómez-Ramos, M. M. et al. (2013) 'Liquid chromatography-high-resolution mass spectrometry for pesticide residue analysis in fruit and vegetables: Screening and quantitative studies', Journal of Chromatography A. Elsevier B.V., 1287, pp. 24-37. doi: 10.1016/j.chroma.2013.02.065.

Gouvinhas, I. et al. (2015) 'Discrimination and characterisation of extra virgin olive oils from three cultivars in different maturation stages using Fourier transform infrared spectroscopy in tandem with chemometrics', Food Chemistry. Elsevier Ltd, 174, pp. 226-232. doi: 10.1016/j.foodchem.2014.11.037.

Govan, F. (2011) 'Spanish saffron scandal as industry accused of importing cheaper foreign varieties', The Telegraph, 31 January. Available at: https://www.telegraph.co.uk/news/worldnews/europe/spain/8293582/Spanish-saffron-scandal-asindustry-accused-of-importing-cheaper-foreign-varieties.html.

Granato, D. et al. (2018) 'Trends in Chemometrics: Food Authentication, Microbiology, and Effects of Processing', Comprehensive Reviews in Food Science and Food Safety, 17(3), pp. 663-677. doi: 10.1111/1541-4337.12341.

Granato, D. and Ares, G. (2014) Mathematical and Statistical Methods in Food Science and Technology. Chichester, UK: John Wiley \& Sons Ltd.

Handford, C. E., Campbell, K. and Elliott, C. T. (2016) 'Impacts of Milk Fraud on Food Safety and Nutrition with Special Emphasis on Developing Countries', Comprehensive Reviews in Food Science and Food Safety, 15(1), pp. 130-142. doi: 10.1111/1541-4337.12181.

Hansen, A.-M. S. (2015) Authenticity of aroma components Enantiomeric separation and compound specific stable isotope analysis. Technical University of Denmark.

Henley, J. (2012) How to tell if your olive oil is the real thing | Life and style | The Guardian, The Guardian.

Hird, S. J. et al. (2014) 'Liquid chromatography-mass spectrometry for the determination of chemical contaminants in food', TrAC - Trends in Analytical Chemistry, 59, pp. 59-72. doi: 10.1016/j.trac.2014.04.005.

Hoffman, B. (2013a) Top 10 'At Risk' Fraudulent Foods And Why You Should Feel Scammed, Forbes. Available at: https://www.forbes.com/sites/bethhoffman/2013/10/23/top-10-at-riskfraudulent-foods-surprising-and-disheartening/\#51950ce15945.

Hoffman, B. (2013b) Top 10 'At Risk' Fraudulent Foods And Why You Should Feel Scammed, Forbes.

de Hoffman, E. and Stroobant, V. (2007) Mass Spectrometry: Principles and Applications. Third Edit. Chichester, UK: John Wiley \& Sons Ltd. 
Hou, B. et al. (2015) 'Development of a sensitive and specific multiplex PCR method for the simultaneous detection of chicken, duck and goose DNA in meat products', Meat Science. Elsevier Ltd, 101, pp. 90-94. doi: 10.1016/j.meatsci.2014.11.007.

Jaiswal, P. et al. (2015a) 'Detection and quantification of soymilk in cow-buffalo milk using Attenuated Total Reflectance Fourier Transform Infrared spectroscopy (ATR-FTIR)', Food Chemistry. Elsevier Ltd, 168, pp. 41-47. doi: 10.1016/j.foodchem.2014.07.010.

Jaiswal, P. et al. (2015b) 'Detection and quantification of soymilk in cow-buffalo milk using Attenuated Total Reflectance Fourier Transform Infrared spectroscopy (ATR-FTIR)', Food Chemistry. Elsevier Ltd, 168, pp. 41-47. doi: 10.1016/j.foodchem.2014.07.010.

Jawaid, S. et al. (2013) 'Rapid detection of melamine adulteration in dairy milk by SB-ATR-Fourier transform infrared spectroscopy’, Food Chemistry. Elsevier Ltd, 141(3), pp. 3066-3071. doi: 10.1016/j.foodchem.2013.05.106.

Johnson, R. (2014) 'Food Fraud and “ Economically Motivated Adulteration ” of Food and Food Ingredients', Congressional Research Service Report, January(R43358), pp. 1-40.

Kazarian, S. G. and Chan, K. L. A. (2013) 'ATR-FTIR spectroscopic imaging: recent advances and applications to biological systems', The Analyst, 138(7), p. 1940. doi: 10.1039/c3an36865c.

Kendall, H. et al. (2018) 'Food fraud and the perceived integrity of European food imports into China’, PLoS ONE, 13(5), pp. 1-27. doi: 10.1371/journal.pone.0195817.

Kery, M. and Royle, J. A. (2016) Applied Hierarchical Modeling in Ecology: Analysis of distribution, abundances and species richness in $R$ and BUGS. Volume 1. Oxford, UK: Academic Press.

Koca, N. et al. (2010) 'Application of temperature-controlled attenuated total reflectance-mid-infrared (ATR-MIR) spectroscopy for rapid estimation of butter adulteration', Food Chemistry. Elsevier Ltd, 121(3), pp. 778-782. doi: 10.1016/j.foodchem.2009.12.083.

Korte, R., Lepski, S. and Brockmeyer, J. (2016) 'Comprehensive peptide marker identification for the detection of multiple nut allergens using a non-targeted LC-HRMS multi-method', Analytical \& Bioanalytical Chemistry, 48(12), pp. 3059-3069. doi: 10.1007/s00216-016-9384-4.

Lakshmi, V. and Pradesh, A. (2012) 'Food Adulteration', 1(2), pp. 106-113.

Lee, F. Y., Htar, T. T. and Akowuah, G. A. (2015) 'ATR-FTIR and Spectrometric Methods for the Assay of Crocin in Commercial Saffron Spices (Crocus savitus L.)', International Journal of Food Properties. Taylor \& Francis, 18(8), pp. 1773-1783. doi: 10.1080/10942912.2014.923911.

Lerma-García, M. J. et al. (2010) 'Authentication of extra virgin olive oils by Fourier-transform infrared spectroscopy', Food Chemistry. Elsevier Ltd, 118(1), pp. 78-83. doi: 10.1016/j.foodchem.2009.04.092.

Li, B. et al. (2015) 'Rapid detection of authenticity and adulteration of walnut oil by FTIR and fluorescence spectroscopy: A comparative study’, Food Chemistry. Elsevier Ltd, 181, pp. 25-30. doi: 10.1016/j.foodchem.2015.02.079.

Li, X., Zhang, Y. and He, Y. (2016) 'Rapid detection of talcum powder in tea using FT-IR spectroscopy coupled with chemometrics', Scientific Reports. Nature Publishing Group, 6(February), pp. 1-8. doi: 10.1038/srep30313.

Lindenberg, C. et al. (2012) 'ATR-FTIR Spectroscopy', in Chianese, A. and Kramer, H. J. . (eds) 
Industrial Crystallization Process Monitoring and Control. 1st edn. Singapore: Wiley-VCH Verlag GmbH \& Co, pp. 81-90.

Lohumi, S. et al. (2014) 'Detection of Starch Adulteration in Onion Powder by FT-NIR and FT-IR Spectroscopy', Journal of Agricultural and Food Chemistry. American Chemical Society, 62(38), pp. 9246-9251. doi: 10.1021/jf500574m.

Lohumi, S. et al. (2017a) 'Quantitative analysis of Sudan dye adulteration in paprika powder using FTIR spectroscopy', Food Additives \& Contaminants: Part A. Taylor \& Francis, 34(5), pp. 678-686. doi: 10.1080/19440049.2017.1290828.

Lohumi, S. et al. (2017b) 'Quantitative analysis of Sudan dye adulteration in paprika powder using FTIR spectroscopy', Food Additives \& Contaminants: Part A. Taylor \& Francis, 34(5), pp. 678-686. doi: 10.1080/19440049.2017.1290828.

Maggio, R. M. et al. (2010) 'A novel chemometric strategy for the estimation of extra virgin olive oil adulteration with edible oils', Food Control. Elsevier Ltd, 21(6), pp. 890-895. doi: 10.1016/j.foodcont.2009.12.006.

Malato, O. et al. (2011) 'Benefits and pitfalls of the application of screening methods for the analysis of pesticide residues in fruits and vegetables', Journal of Chromatography A. Elsevier B.V., 1218(42), pp. 7615-7626. doi: 10.1016/j.chroma.2011.06.110.

Marieschi, M. et al. (2011a) 'Detecting Satureja montana L. and Origanum majorana L. by means of SCAR-PCR in commercial samples of Mediterranean oregano', Food Control. Elsevier Ltd, 22(3-4), pp. 542-548. doi: 10.1016/j.foodcont.2010.10.001.

Marieschi, M. et al. (2011b) 'Development of a SCAR marker for the identification of Olea europaea L.: A newly detected adulterant in commercial Mediterranean oregano', Food Chemistry. Elsevier Ltd, 126(2), pp. 705-709. doi: 10.1016/j.foodchem.2010.11.030.

Marieschi, M., Torelli, A. and Bruni, R. (2012) 'Quality Control of Saffron (Crocus sativus L.): Development of SCAR Markers for the Detection of Plant Adulterants Used as Bulking Agents', Journal of agricultural and food chemistry, 60, pp. 10998-11004.

Meza-Márquez, O. G., Gallardo-Velázquez, T. and Osorio-Revilla, G. (2010) ‘Application of midinfrared spectroscopy with multivariate analysis and soft independent modeling of class analogies (SIMCA) for the detection of adulterants in minced beef', Meat Science. Elsevier Ltd, 86(2), pp. 511519. doi: 10.1016/j.meatsci.2010.05.044.

Miaw, C. S. W. et al. (2018) 'Determination of main fruits in adulterated nectars by ATR-FTIR spectroscopy combined with multivariate calibration and variable selection methods', Food Chemistry. Elsevier, 254(October 2017), pp. 272-280. doi: 10.1016/j.foodchem.2018.02.015.

Michelson, A. A. (1881) 'Interference phenomena in a new form of refractometer', Philosophical Magazine, 13, pp. 236-242.

Michelson, A. A. (1927) Studies in Optics. Chicago: University of Chicago Press.

Mohamed, G. F. et al. (2011) 'Application of FT-IR Spectroscopy for Rapid and Simultaneous Quality Determination of Some Fruit Products', Nature and Science, 9(11), pp. 21-31.

Moore, J. C., Spink, J. and Lipp, M. (2012) 'Development and Application of a Database of Food Ingredient Fraud and Economically Motivated Adulteration from 1980 to 2010', Journal of Food Science, 77(4). doi: 10.1111/j.1750-3841.2012.02657.x. 
Nunes, K. M. et al. (2016a) 'Detection and characterisation of frauds in bovine meat in natura by nonmeat ingredient additions using data fusion of chemical parameters and ATR-FTIR spectroscopy', Food Chemistry. Elsevier Ltd, 205, pp. 14-22. doi: 10.1016/j.foodchem.2016.02.158.

Nunes, K. M. et al. (2016b) 'Detection and characterisation of frauds in bovine meat in natura by nonmeat ingredient additions using data fusion of chemical parameters and ATR-FTIR spectroscopy', Food Chemistry. Elsevier Ltd, 205, pp. 14-22. doi: 10.1016/j.foodchem.2016.02.158.

Nurrulhidayah, A. F. et al. (2015) 'FTIR-ATR spectroscopy based metabolite fingerprinting as a direct determination of butter adulterated with lard', International Journal of Food Properties. Taylor \& Francis, 18(2), pp. 372-379. doi: 10.1080/10942912.2012.692224.

Nyquist, R. A. and Kagel, R. O. (2012) Handbook of Infrared and Raman Spectra of Inorganic Compounds and Organic Salts: Infrared Spectra of Inorganic Compounds. London: Academic Press.

Ok, S. (2017) 'Detection of olive oil adulteration by low-field NMR relaxometry and UV-Vis spectroscopy upon mixing olive oil with various edible oils', Grasas y Aceites, 68(1), p. 173. doi: 10.3989/gya.0678161.

Ordoudi, S. A. et al. (2017) 'Uncovering a challenging case of adulterated commercial saffron', Food Control. Elsevier Ltd, 81, pp. 147-155. doi: 10.1016/j.foodcont.2017.05.046.

Pei, X. et al. (2011) 'The China melamine milk scandal and its implications for food safety regulation', Food Policy. Elsevier Ltd, 36(3), pp. 412-420. doi: 10.1016/j.foodpol.2011.03.008.

Pérez-Ortega, P. et al. (2016) 'A feasibility study of UHPLC-HRMS accurate-mass screening methods for multiclass testing of organic contaminants in food', Talanta. Elsevier, 160, pp. 704-712. doi: 10.1016/j.talanta.2016.08.002.

Petrakis, E. A. and Polissiou, M. G. (2017) 'Assessing saffron (Crocus sativus L.) adulteration with plant-derived adulterants by diffuse reflectance infrared Fourier transform spectroscopy coupled with chemometrics', Talanta. Elsevier, 162(October 2016), pp. 558-566. doi: 10.1016/j.talanta.2016.10.072.

Pieke, E. N., Smedsgaard, J. and Granby, K. (2017) 'Exploring the chemistry of complex samples by tentative identification and semiquantification: A food contact material case', Journal of Mass Spectrometry, 53(4), pp. 323-335.

Premanandh, J. (2013) 'Horse meat scandal - A wake-up call for regulatory authorities', Food Control. Elsevier Ltd, 34(2), pp. 568-569. doi: 10.1016/j.foodcont.2013.05.033.

Primrose, S., Woolfe, M. and Rollinson, S. (2010) 'Food forensics: Methods for determining the authenticity of foodstuffs', Trends in Food Science and Technology. Elsevier Ltd, 21(12), pp. 582590. doi: 10.1016/j.tifs.2010.09.006.

PwC (2016) 'Food Fraud Vulnerability Assessment and Mitigation', PricewaterhouseCoopers, pp. 120.

Quiñones-Islas, N. et al. (2013) 'Detection of adulterants in avocado oil by Mid-FTIR spectroscopy and multivariate analysis', Food Research International. Elsevier Ltd, 51(1), pp. 148-154. doi: 10.1016/j.foodres.2012.11.037.

Reis, N. et al. (2017) 'Simultaneous Detection of Multiple Adulterants in Ground Roasted Coffee by ATR-FTIR Spectroscopy and Data Fusion', Food Analytical Methods, 10(8), pp. 2700-2709. 
Rios-Corripio, M. A. et al. (2011) 'FTIR characterization of Mexican honey and its adulteration with sugar syrups by using chemometric methods', Journal of Physics: Conference Series, 274(1), pp. 0-5. doi: 10.1088/1742-6596/274/1/012098.

Ríos-Reina, R. et al. (2017) 'ATR-FTIR as a potential tool for controlling high quality vinegar categories', Food Control, 78, pp. 230-237. doi: 10.1016/j.foodcont.2017.02.065.

Rodriguez-Saona, L. E. and Allendorf, M. E. (2012) 'Use of FTIR for Rapid Authentication and Detection of Adulteration of Food', Annual Review of Food Science and Technology, 2(1), pp. 467483. doi: 10.1146/annurev-food-022510-133750.

Rohman, A. et al. (2011) 'Analysis of pork adulteration in beef meatball using Fourier transform infrared (FTIR) spectroscopy', Meat Science. The American Meat Science Association, 88(1), pp. 9195. doi: 10.1016/j.meatsci.2010.12.007.

Rohman, A. and Man, Y. B. C. (2010) 'Fourier transform infrared (FTIR) spectroscopy for analysis of extra virgin olive oil adulterated with palm oil', Food Research International. Elsevier Ltd, 43(3), pp. 886-892. doi: 10.1016/j.foodres.2009.12.006.

Rubert, J. et al. (2016) 'Saffron authentication based on liquid chromatography high resolution tandem mass spectrometry and multivariate data analysis', Food Chemistry. Elsevier Ltd, 204, pp. 201-209. doi: 10.1016/j.foodchem.2016.01.003.

Salzer, R. and Siesler, H. W. (2014) Infrared and Raman Spectroscopic Imaging. Weinheim: WileyVCH Verlag GmbH \& Co.

Santos, P. M., Pereira-Filho, E. R. and Rodriguez-Saona, L. E. (2013) 'Rapid detection and quantification of milk adulteration using infrared microspectroscopy and chemometrics analysis', Food Chemistry. Elsevier Ltd, 138(1), pp. 19-24. doi: 10.1016/j.foodchem.2012.10.024.

Schrieberg, D. (2017) Stock Up On Olive Oil Because Prices Are Skyrocketing, Forbes. Available at: https://www.forbes.com/sites/davidschrieberg 1/2017/05/27/stock-up-on-olive-oil-because-prices-areskyrocketing/\#2311d02f7757 (Accessed: 23 August 2018).

Sicherer, S. H., Burks, a W. and Sampson, H. a (1998) 'Clinical features of acute allergic reactions to peanut and tree nuts in children.', Pediatrics, 102(1), p. e6. doi: 10.1542/peds.102.1.e6.

Sim, C. et al. (2004) 'Assessment of Herbal Medicines by Chemometrics - Assisted Interpretation of FTIR Spectra', Analytica chimica acta, (January 2004), pp. 1-14.

Simmons, I. L. (1960) 'The Kbr Technique’, (3), pp. 1-8.

Sivakesava, S. and Irudayaraj, J. (2001) 'Detection of inverted beet sugar adulteration of honey by FTIR spectroscopy', Journal of the Science of Food and Agriculture, 81(8), pp. 683-690. doi: $10.1002 /$ jsfa.858.

Skinner, C. G., Thomas, J. D. and Osterloh, J. D. (2010) 'Melamine toxicity', Journal of Medical Toxicology, 6(1), pp. 50-55. doi: 10.1007/s13181-010-0038-1.

Smith, R., Manning, L. and McElwee, G. (2017) 'Critiquing the inter-disciplinary literature on food fraud', International Journal of Rural Criminology, 3(2), pp. 250-270.

Spink, J. and Moyer, D. C. (2011) 'Defining the Public Health Threat of Food Fraud', Journal of Food Science, 76(9). doi: 10.1111/j.1750-3841.2011.02417.x. 
Stuart, B. (2005) Infrared Spectroscopy: Fundamentals and Applications. John Wiley \& Sons, Ltd. doi: 10.1002/0470011149.

Sun, D.-W. (2009) Infrared Spectroscopy for Food Quality Analysis and Control. First. Burlington, MA, USA: Academic Press.

Tasumi, M. (2015) Introduction to Experimental Infrared Spectroscopy: Fundamentals and Practical Methods. Chichester, UK: John Wiley \& Sons Ltd.

The Associated Press (2008) China's top food safety official resigns, NBC News. Available at: http://www.nbcnews.com/id/26827110/\#.W30iicJJlhE.

The Council of the European Union (2006) 'COUNCIL REGULATION (EC) No 510/2006 of 20 March 2006 on the protection of geographical indications and designations of origin for agricultural products and foodstuffs', 2006(510), pp. 12-25.

The European Commission (2014a) 'COMMISSION DELEGATED REGULATION (EU) No 664/2014 of 18 December 2013 supplementing Regulation (EU) No 1151/2012 of the European Parliament and of the Council with regard to the establishment of the Union symbols for protected designations of origin, prote', 2014(886).

The European Commission (2014b) 'COMMISSION IMPLEMENTING REGULATION (EU) No 668/2014 of 13 June 2014 laying down rules for the application of Regulation (EU) No 1151/2012 of the European Parliament and of the Council on quality schemes for agricultural products and foodstuffs', 59(May), pp. 35-59.

United States Congress (1938) Federal Food, Drug, and Cosmetic Act (FFCDA). United States Food and Drug Administration.

United States Congress (2011) FDA Food Safety Modernization Act. US FDA.

US FDA (2018) Defect Levels Handbook. Available at:

https://www.fda.gov/Food/GuidanceRegulation/GuidanceDocumentsRegulatoryInformation/Sanitatio nTransportation/ucm056174.htm\#CHPTA (Accessed: 30 August 2018).

US Food and Drug Administration (2009) 'Economically Motivated Adulteration; Public Meeting; Request for Comment', Fed Register, 74(64), pp. 15497-9.

Vidal, R., Ma, Y. and Sastry, S. (2016) Generalized Principal Component Analysis. New York, NY: Springer-Verlag New York. doi: 10.007/978-0-387-87811-9.

Villa, C. et al. (2016) 'Exploiting DNA mini-barcodes as molecular markers to authenticate saffron (Crocus sativus L.)', Food Control. Elsevier Ltd, 65, pp. 21-31. doi: 10.1016/j.foodcont.2016.01.008.

Wielogorska, E. et al. (2018) 'Development of a comprehensive analytical platform for the detection and quantitation of food fraud using a biomarker approach. The oregano adulteration case study', Food Chemistry. Elsevier Ltd, 239, pp. 32-39. doi: 10.1016/j.foodchem.2017.06.083. 